\title{
Genesis, classification and evaluation of cotton growing soils in semi arid tropics of Tamil Nadu
}

\section{RAJESHWAR MALAVATH AND S.MANI}

Received : 24.12.2014; Revised : 07.05.2015; Accepted : 19.05.2015

\section{MEMBERS OF RESEARCH FORUM:}

Corresponding author : RAJESHWAR MALAVATH, Department of Soil Science and Agricultural Chemistry, College of Agriculture, Professor Jayashankar Telangana State Agricultural University, Rajendranagar, HYDERABAD (TELANGANA) INDIA Email: rajeshoct31naik@gmail.com

Co-authors :

S. MANI, Department of Soil Science and Agricultural Chemistry, Agricultural College and Research Institute, Tamil Nadu Agricultural University, COIMBATORE (T.N.) INDIA

\section{Summary}

The study was carried out in the new research station of Tamil Nadu Agricultural University at Cotton Research Station, Veppanthatai of Perambalur district of Tamil Nadu was selected for developing the strong soil resource database for proper appraisal of their productivity potential and their rational use. This study was an embodiment with an objective of characterization, classification and evaluation of some black cotton soils in semi arid tropical region of Tamil Nadu. The black soils of CRS, Veppanthattai were formed at nearly level to plain topography on granitic gneiss parent material mixed with calcareous murram. The soil colour varied from very dark gray to dark grayish brown under dry and moist condition, respectively. The soils were very deep. The textural class of fine earth fraction was clayey and had coarse strong angular blocky structure. The clay content ranged from 52.9 to 64.3 per cent. The silt content in most of the pedons showed an irregular trend with soil depth. The sand content varied from 19.7 to 30.1 per cent. Bulk density increased with increasing depth. The moisture retention at field capacity $(33 \mathrm{kpa})$, permanent wilting point $(1500 \mathrm{kpa})$ and available water capacity were high. The $\mathrm{pH}$ values ranged from moderately alkaline (8.48) to strongly alkaline (9.13). The electrical conductivity of the pedons ranged from 0.14 to $0.72 \mathrm{dS} \mathrm{m}^{-1}$ indicating that these soils were non-saline in nature. The organic carbonstatus was medium (5.4 to $5.5 \mathrm{~g} \mathrm{~kg}^{-1}$ ) in surface horizons, whereas, in subsurface horizons it was low and ranged from 0.70 to $4.6 \mathrm{~g} \mathrm{~kg}^{-1}$. The $\mathrm{CaCO}_{3}$ content varied from 7.3 to 15.5 per cent. The cation exchange capacity of soils was high [44.6 to $48.8 \mathrm{c} \mathrm{mol}\left(\mathrm{p}^{+}\right) \mathrm{kg}^{-1}$ ]. The exchangeable bases were high and in the order of $\mathrm{Ca}^{+2}>\mathrm{Mg}^{+2}>$ $\mathrm{Na}^{+}>\mathrm{K}^{+}$on the exchange complex. Based on the morphology, physical, physico-chemical, and chemical properties of the soils, pedons were classified as per USDA soil taxonomy into orders Vertisols. The soils are very deep and ideal for cultivation of cotton, sorghum, soybean, greengram, blackgram, redgram, sunflower, sesamum, maize and pearlmillet.

Key words : Genesis, Classification, Evaluation, Soil characterization

How to cite this article : Malavath, Rajeshwar and Mani, S. (2015). Genesis, classification and evaluation of cotton growing soils in semi arid tropics of Tamil Nadu. Asian J. Soil Sci., 10(1) : 130-141. 